\title{
Macromolecular components of genital tract fluids from the sheep
}

\author{
G. P. Roberts*, J. M. Parker and H. W. Symonds \\ Agricultural Research Council, Institute for Research on Animal Diseases, \\ Compton, Nr Newbury, Berkshire, U.K.
}

\begin{abstract}
Summary. The proteins and glycosidases in the luminal fluid from the genital tract of ewes at different stages of the oestrous cycle and early pregnancy were studied. Most of the proteins in oviducal fluid and uterine fluid were serum proteins, but an increased amount of a glycoprotein excluded from Sephadex G-200 was detected in oviducal fluid at oestrus. Small amounts of uterine-specific proteins were detected in uterine fluid by polyacrylamide gel electrophoresis and isoelectric focusing. The number of these varied according to the stage of pregnancy. The activities of several glycosidases were elevated in uterine fluid when compared with serum; $\beta$ - $N$-acetylgalactosaminidase and $\beta-N$-acetylglucosaminidase were particularly active. Ovine cervical mucus was shown to contain an epithelial glycoprotein which had a composition similar to that of the glycoproteins isolated from human and bovine cervical mucus.
\end{abstract}

\section{Introduction}

The luminal fluids of the female genital tract constitute the environment in which spermatozoa, eggs and zygotes survive and function. That the constitutents of these fluids influence early reproductive events has been shown in many investigations. For instance, the importance of the physical properties of cervical secretions in producing a sperm reservoir after mating has been well established for ruminants (Mattner, 1966; Gibbons \& Mattner, 1971). Capacitation of spermatozoa by uterine or oviducal fluid is a prerequisite for successful fertilization in many species (Bedford, 1970; Chang, 1972), and the importance of the correct uterine environment for successful embryonic development in ruminants is inferred from the need for synchronization between donor and recipient in embryo transplant experiments (Rowson \& Moor, 1966; Rowson, Lawson, Moor \& Baker, 1972). A knowledge of the biochemical components which constitute the luminal fluids of the female genital tract and the changes which occur in these during pregnancy would aid the interpretation of these early reproductive events and permit a definitive approach to the control or augmentation of fertility. The purpose of the present study was to investigate the macromolecular components of cervical, uterine and oviducal fluids from sheep, with particular emphasis on a search for proteins unique to the genital tract. In view of the importance of glycolipids and glycoproteins on mammalian cell surfaces (Winzler, 1972; Hughes, 1973), the activities of a number of glycosidases which might modify these glycoconjugates have also been determined.

\section{Materials and Methods}

\section{Animals}

The animals used were Herdwick ewes from the Institute's flock. One oviduct of each of 8 ewes was cannulated as described previously for the cow (Roberts, Parker \& Symonds, 1975). The collect-

\footnotetext{
* Present address: Department of Surgery, Welsh National School of Medicine, Heath Park, Cardiff CF4 4XN, Wales.
} 
ing device for the oviducal fluids was similar to that used for the cow but a 2-ml instead of a 5-ml disposable syringe was used.

Another group of 21 ewes was housed in batches of 4 with a raddled ram and examined twice daily for colour marks. The day on which behavioural oestrus was first detected was taken as Day 0 of the cycle. Oestrous behaviour in the three unmated controls was detected using a vasectomized ram. After the appropriate experimental period the animals were slaughtered and the genital tract excised as rapidly as possible, usually within $2-3 \mathrm{~min}$ of death. The uterus was clamped above the cervix and the two horns of the uterus dissected out and flushed three times with $3 \mathrm{ml} 0.15 \mathrm{M}-\mathrm{NaCl}$, care being taken to cover the exposed cut muscular tissues with a paper towel. The washings were centrifuged to remove debris and the sediment was microscopically examined for the embryo. There was no visible contamination with blood in any of the washings nor in the sediments. Two procedures were used to concentrate the proteins in the supernatant phase: (1) the rinsings from 6 of the sheep were dialysed to zero ionic strength and freeze dried, and (2) the rinsings from the other 15 sheep were concentrated by ultrafiltration using Visking dialysis tubing ( $6 \mathrm{~mm}$ inflated diameter) with a negative pressure of $600 \mathrm{mmHg}$.

Cervical mucus $(0.66 \mathrm{ml})$ was collected from three 12-day and three 13-day pregnant sheep by opening the cervical canal and transferring the surface mucus onto a glass slide by a gentle scraping action. The soluble proteins were removed by washing the mucus four times with $3 \mathrm{ml} 0.15 \mathrm{M}-\mathrm{NaCl}$ and the washed mucus was dissolved in $6 \mathrm{M}$-guanidine hydrobromide at room temperature over $24 \mathrm{hr}$. Small amounts of cellular debris were removed by filtration through glass wool and the viscous filtrate centrifuged at $260,000 \mathrm{~g}$ for $48 \mathrm{hr}$ at $20^{\circ} \mathrm{C}$. Glycoproteins sedimented to the bottom of the tube under these conditions, whereas proteins were recovered in the upper third of the tube (Gibbons \& Sellwood, 1973). These fractions were dialysed to zero ionic strength and freeze dried.

\section{Methods}

Polyacrylamide disc electrophoresis was carried out at pH 8.9 as described by Davis (1964) and at pH 4.5 as described by Reisfeld, Lewis \& Williams (1962). Naphthalene black 12 B (BDH Chemicals Ltd, Poole, Dorset) was used to stain proteins and a PAS-staining procedure (Zaccharius, Zell, Morrison \& Woodlock, 1969) for glycoproteins. Isoelectric focusing was performed as described by Awdeh, Williamson \& Askonas (1968).

Gel filtration was carried out on a column of Sephadex $\mathrm{G}-200(1.5 \mathrm{~cm} \times 85 \mathrm{~cm})$ at $4^{\circ} \mathrm{C}$ using $0.02 \mathrm{M}$-sodium phosphate-citrate buffer, $\mathrm{pH} 7.4$, which contained $0.02 \%(\mathrm{w} / \mathrm{v})$ sodium azide for elution.

Antiserum to ovine serum was prepared in rabbits as described previously for bovine serum (Roberts \& Parker, 1974a), and immunoelectrophoresis was carried out by the method of Scheidegger (1955). The antiserum was used to prepare an immunosorbent as described elsewhere for bovine serum antiserum (Roberts, Parker \& Symonds, 1975). The immunosorbent had a capacity to absorb $1.5 \mathrm{mg}$ serum proteins/ml gel. Oviducal secretion $(150 \mu \mathrm{l})$ was mixed with $150 \mu \mathrm{l} 0.2$ M-sodium citrate buffer, $\mathrm{pH} 6.5$, containing $0.15 \mathrm{M}-\mathrm{NaCl}$ and put on a column $(0.6 \mathrm{~cm} \times 8 \mathrm{~cm})$ of the immunosorbent. Elution was carried out with the citrate buffer at an elution rate of $20 \mathrm{ml} / \mathrm{hr}$. Fractions $(10 \mathrm{ml})$ were collected and the extinction monitored at $280 \mathrm{~nm}$ in a $1-\mathrm{cm}$ cell using a Unicam SP1800 u.v. spectrophotometer. The fractions containing protein were dialysed and freeze dried.

\section{Assays}

The enzymes ( $\alpha$-L-fucosidase, $\beta$-L-fucosidase, $\alpha$-D-galactosidase, $\beta$-D-galactosidase, $\alpha$-D-glucosidase, $\beta$-D-glucosidase, $\beta$ - $N$-acetylgalactosaminidase, $\beta$ - $N$-acetylglucosaminidase, $\alpha$-D-mannosidase and $\beta$-D-mannosidase) were assayed at $\mathrm{pH} 5.0$ using the corresponding $p$-nitrophenyl glycosides as described previously (Roberts \& Parker, 1974b).

Total hexose, fucose, total hexosamine deoxyribonucleic acid, nitrogen and protein were determined by methods described elsewhere (Roberts, Parker \& Symonds, 1975). Neuraminic acid was assayed by the direct Ehrlich reaction (Werner \& Odin, 1952). Glucosamine and galactosamine were 
assayed as described by Good \& Bessman (1964). Amino acids were determined after hydrolysis with $6 \mathrm{~N}-\mathrm{HCl}$ at $110^{\circ} \mathrm{C}$ for $24 \mathrm{hr}$ in vacuo and using nor-leucine as an internal standard (Hamilton, 1963). An alkaline $\beta$-elimination and reduction reaction was carried out on an aqueous solution of the glycoprotein from ovine cervical mucus using the conditions described by Downs, Herp, Moschera \& Pigman (1973).

Paper chromatography was carried out on Whatman No. 1 paper using the descending technique in butan-1-ol:propan-1-ol:0.1 $\mathrm{N}-\mathrm{HCl}(1: 2: 1$ by vol.) and sialic acids were detected using a thiobarbituric acid spray (Warren, 1960).

\section{Results}

\section{Oviduct}

Secretion rates. Oviducal fluid was collected daily from the 8 ewes for periods ranging from 2 weeks to 45 weeks. After 2 or 3 oestrous cycles the sheep were housed with a raddled ram and the time of mating noted. Ewes A, B, C, D and E lambed and oviducal fluid was collected from three (A, B and C) throughout pregnancy. The secretion rate of oviducal fluid from Ewe G during one complete oestrous cycle before mating is shown in Text-fig. 1. In all the ewes maximum secretion of oviducal fluid occurred around oestrus and was reduced during dioestrus. During pregnancy the secretion rate was similar to that during dioestrus but more fluid was secreted during the $24 \mathrm{hr}$ after parturition. The protein content of the oviducal fluid varied widely, the range for the 8 sheep being 3-63 mg protein $/ \mathrm{ml}$. A wide variation in protein content was also observed in individual sheep and this variation did not appear to bear any relation to the stage of the oestrous cycle or pregnancy.

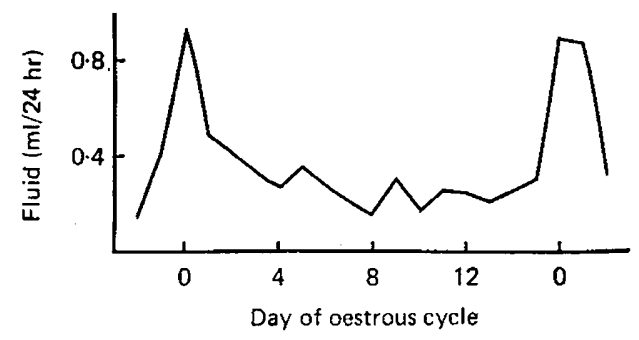

Text-fig. 1. Daily volumes of oviducal fiuid collected from Ewe $G$ throughout one oestrous cycle.

Gel electrophoresis. Electrophoresis at $\mathrm{pH} 8.9$ of 30 samples of oviducal fluid from Ewes A, B, C, F and $\mathrm{G}$ at various times throughout the oestrous cycle and pregnancy resulted in protein patterns virtually identical to those obtained with serum except for a fainter $\gamma$-globulin band in the oviducal samples. Duplicate gels stained with PAS revealed that the oviducal glycoprotein patterns were also similar to the serum glycoprotein pattern.

The protein patterns obtained by electrophoresis at $\mathrm{pH} 4.5$ of oviducal fluid sampled during the oestrous cycle were similar to the patterns obtained with serum, but when the sheep were $>14$ days pregnant small amounts of two or three bands which migrated rapidly towards the cathode were seen in all 8 samples examined. These proteins, which were not detected in serum, had $M a / b$ values $=1 \cdot 15,1.23$ and 1.42 where $M a / b$ is defined as the mobility of the protein relative to that of the leading edge of the albumin band.

The proteins in 10 samples of oviducal fluid selected from various stages of the oestrous cycle and pregnancy were resolved into 25 bands by isoelectric focusing using an ampholyte mixture with $\mathrm{pH}$ range 3-10. All these bands were also detected in serum. The small amounts of oviducal proteins seen in samples from sheep $>14$ days pregnant by electrophoresis at $\mathrm{pH} 4.5$ were not detected by isoelectric focusing, probably because of masking by serum proteins.

Immunoelectrophoresis of oviducal fluid from Ewes $A$ and $G$ at various stages of the oestrous 
cycle and pregnancy gave up to 10 precipitin arcs when antiserum to ovine serum was used, compared with the 12 precipitin arcs with ovine serum.

Affinity chromatography. Most of the serum proteins in oviducal fluid sampled from Ewe $\mathrm{G}$ at oestrus were absorbed on the immunosorbent column. The eluate, obtained by eluting the column with $0 \cdot 2 \mathrm{M}$-citrate buffer, $\mathrm{pH} 6 \cdot 2 / 0 \cdot 15 \mathrm{M}-\mathrm{NaCl}$, contained some serum albumin and traces of transferrin but no other proteins were detected by electrophoresis.

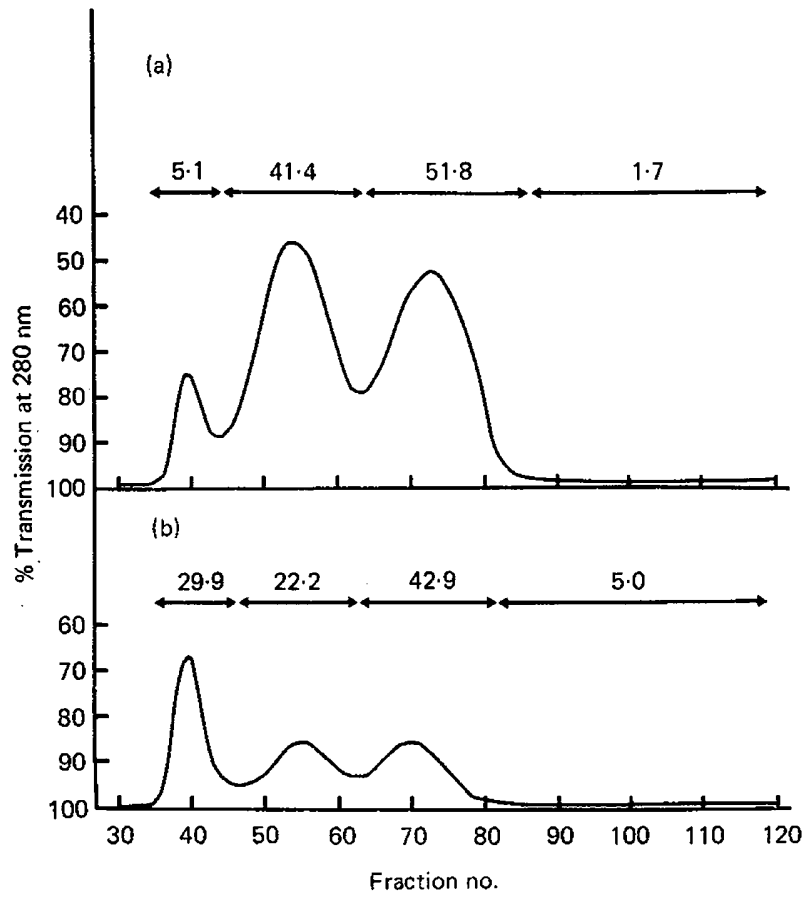

Text-fig. 2. Protein distribution from columns $(1.5 \mathrm{~cm} \times 85 \mathrm{~cm})$ of Sephadex $\mathrm{G}-200$ of (a) ovine serum, and (b) oviducal fluid from Ewe $G$ at oestrus. Fractions were combined as indicated by the horizontal bars and the amount of material recovered in each fraction is expressed as a $\%$ of the total by the numbers above the bar.

Gel filtration. The protein elution patterns of serum and oviducal fluid from Ewe $\mathrm{G}$ at oestrus are shown in Text-fig. 2. Three peaks were obtained with both samples but the amount of the first peak relative to the other two was greater with oviducal fluid than with serum. The fractions shown in Text-fig. 2 were examined by gel electrophoresis at $\mathrm{pH} 4 \cdot 5$ and $\mathrm{pH} 8.9$ but no differences were detected between the corresponding serum and oviducal fractions, F2, F3 and F4. Fractions F1 were of high molecular weight and were mainly excluded from the polyacrylamide gels. Analysis of these revealed that Fraction F1 of oviducal fluid contained $11.4 \%$ total hexose, $5.8 \%$ hexosamine and $1.9 \%$ sialic acid, whereas Fraction F1 of serum contained $5.1 \%$ total hexose, $2.4 \%$ hexosamine and $0.8 \%$ sialic acid.

Glycosidases. The activities of all the glycosidases were low in oviducal fluid from Ewes A and G sampled at a number of times during the oestrous cycle and pregnancy. At oestrus, the activities were similar to those obtained with serum when expressed as $\mu \mathrm{g} p$-nitrophenol released/mg protein. During dioestrus and pregnancy, the activities of $\beta-N$-acetylgalactosaminidase and $\beta$ - $N$-acetylglucosaminidase in oviducal fluid were increased fourfold when compared with serum.

\section{Uterine fluid}

Amount of protein. The amount of protein in saline washings of ovine uteri was small, 3-7 mg 
being obtained per uterus during the first 13 days of pregnancy and 12-20 mg between Days 14 and 18 of pregnancy.

Gel electrophoresis. The electrophoretic pattern obtained at $\mathrm{pH} 8.9$ using uterine washings from a 15-day pregnant sheep after concentration by ultrafiltration is compared with that of serum in Text-fig. 3. Whereas the major bands of the uterine washings corresponded with serum proteins, 8 of the bands with $M a / b=0.07,0.11,0.45,0.69,0.74,1.05,1.12$ and 1.17 were not detected in serum. Most of the latter were also detected as faint bands in the electrophoretic patterns of uterine washings from 7-, 11- and 13-day pregnant sheep but the bands with $M a / b=1.05$ and 1.17 appeared to depend on the stage of pregnancy and were only detected in samples from sheep which were 15 or 18 days pregnant. In addition, the band with $M a / b=0.69$ was increased in intensity in samples from 15- or 18-day pregnant sheep.
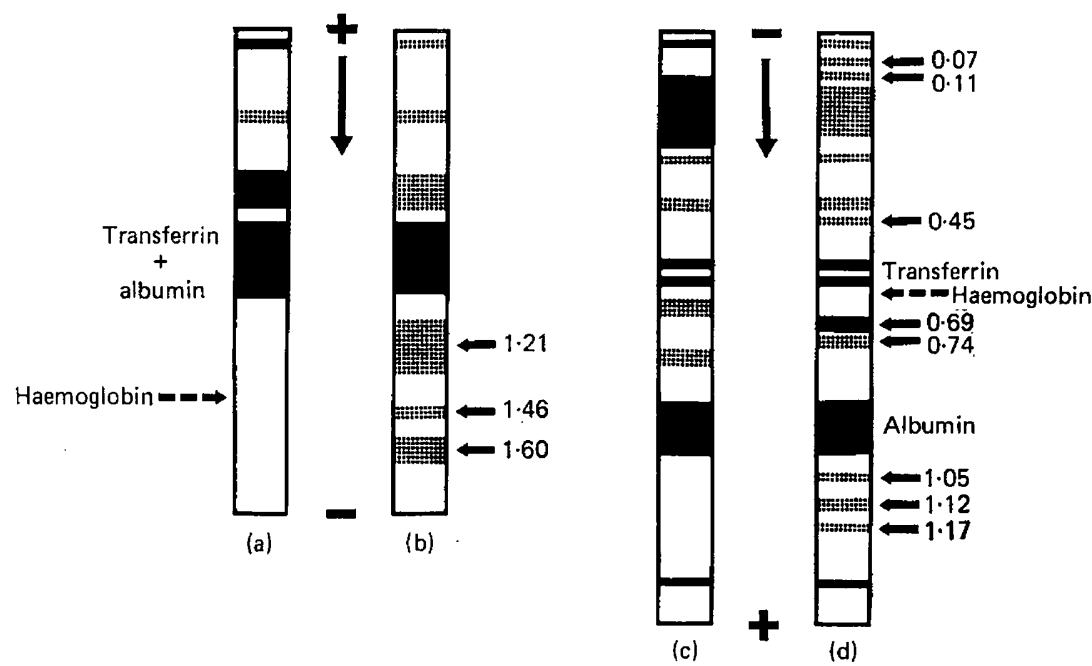

Text-fig. 3. Comparison of polyacrylamide gel electrophoretic patterns at $\mathrm{pH} 4 \cdot 5$ ((a) and (b)) and $\mathrm{pH} 8.9$ $((c)$ and $(d))$ of ovine serum ((a) and (c)) and ovine uterine washings from a 15-day pregnant sheep ((b) and (d)). The uterine-specific bands are indicated by the right-hand solid arrows and their migration rates relative to albumin $(\mathrm{Ma} / \mathrm{b})$ shown by the numbers. The bands of albumin and transferrin are labelled and the position at which ovine haemoglobin migrates is arrowed.

Electrophoresis of the uterine proteins at $\mathrm{pH} 4.5$ revealed that the patterns obtained varied with the two methods used for concentrating the proteins. More protein bands were detected after ultrafiltration than in samples concentrated by dialysis and freeze drying, and so the latter method was abandoned. In addition to proteins detected in serum, three bands migrating rapidly to the cathode with $M a / b=1.21,1.46$ and 1.60 were observed in the electrophoretograms of uterine samples (Textfig. 3) from ewes $7,11,13,15$ and 18 days pregnant. One of these bands $(M a / b=1 \cdot 21)$ was rather diffuse and was increased in intensity in the samples from 15- and 18-day pregnant sheep.

Gel isoelectric focusing of the uterine proteins isolated by ultrafiltration from unmated sheep at Days 13 and 15 of the oestrous cycle and 11-, 13- and 15-day pregnant sheep gave up to 32 bands. Most of the major bands were also present in serum but in the uterine washings from a 15-day pregnant sheep 10 bands were found which were not detected in serum (Text-fig. 4). Five of these bands which had isoelectric points (pI) of 5.7, 6.4, 6.7, 6.8 and $7 \cdot 0$ were also detected in uterine washings from unmated sheep or sheep at earlier stages of pregnancy, but the other five bands ( $\mathrm{pI}=4 \cdot 3,4 \cdot 5,4 \cdot 6$, $5 \cdot 3$ and 5.6 ) were only detected in the uterine washings from a 15-day pregnant sheep.

Glycosidases. The activities of $\beta$-L-fucosidase, $\alpha$-D-galactosidase, $\beta$-D-glucosidase, $\alpha$ - and $\beta$-D-mannosidase in uterine washings from sheep which were $7,11,13,15$ and 18 days pregnant, although elevated when compared to serum, were all low. Less than $10 \mu \mathrm{g} p$-nitrophenol was released/ 


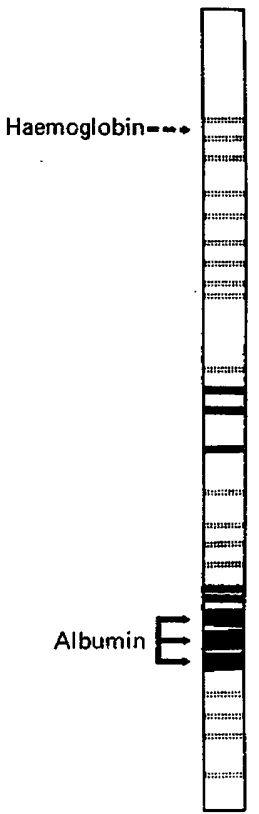

(a)

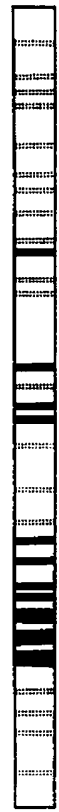

(b)

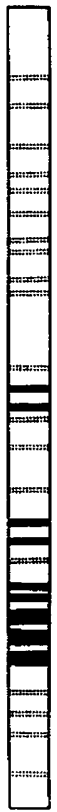

\{c\}

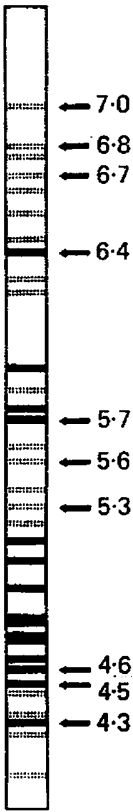

(d)

Text-fig. 4. Isoelectric focusing in polyacrylamide gel containing $\mathrm{pH} 3$ to 10 ampholytes of (a) ovine serum, (b) uterine washings from a 13-day pregnant sheep, (c) uterine washings from an unmated sheep at Day 15 of the oestrous cycle, and (d) uterine washings from a 15-day pregnant sheep. The uterine-specific bands are indicated by the right-hand arrows and their isoelectric points (pI) shown by the numbers.

$\mathrm{mg}$ protein in $1 \mathrm{hr}$ from each substrate in the assay system used. However, the activities of $\alpha$-L-fucosidase, $\beta$-D-galactosidase, $\alpha$-D-glucosidase, $\beta$ - $N$-acetylgalactosaminidase and $\beta$ - $N$-acetylglucosaminidase were considerably elevated when compared with serum (Table 1). Highest levels were observed between Days 11 and 15 of pregnancy but the activities of these enzymes in uterine washings from unmated sheep at Days 13 and 15 of the oestrous cycle were considerably lower.

Table 1. Glycosidase activities of proteins from ovine uterine fluid

\begin{tabular}{|c|c|c|c|c|c|}
\hline & \multicolumn{5}{|c|}{ Enzymatic activities ( $\mu \mathrm{g} p$-nitrophenol released/mg protein/hr) } \\
\hline & $\alpha$-L-Fucosidase & $\beta$-D-Galactosidase & $\alpha$-D-Glucosidase & $\begin{array}{l}\beta-N \text {-acetyl- } \\
\text { galactosamin- } \\
\text { idase }\end{array}$ & $\begin{array}{l}\beta-N \text {-acetyl- } \\
\text { glucosamin- } \\
\text { idase }\end{array}$ \\
\hline $\begin{array}{l}\text { Serum* } \\
\text { Pregnant sheep: }\end{array}$ & 0.01 & 0.02 & 0.05 & $1 \cdot 1$ & $1 \cdot 1$ \\
\hline Day 7 & $9 \cdot 4$ & $3 \cdot 3$ & $1 \cdot 4$ & 1040 & 4540 \\
\hline Day 11 & $50 \cdot 8$ & $4 \cdot 3$ & $3 \cdot 5$ & 3133 & 9400 \\
\hline Day 13 & $41 \cdot 2$ & 15.9 & $11 \cdot 6$ & 2533 & 9700 \\
\hline Day 15 & $50 \cdot 8$ & $13 \cdot 8$ & $19 \cdot 1$ & 2493 & 3260 \\
\hline Day 18 & 11.7 & $3 \cdot 7$ & 2 & 1217 & 4000 \\
\hline Non-pregnant sh & & & & & \\
\hline Day 13 & 25 & $3 \cdot 3$ & N.D. & 579 & 3260 \\
\hline Day 15 & 4 & $1 \cdot 3$ & N.D. & 93 & 80 \\
\hline
\end{tabular}

* The serum was taken from a 13-day pregnant sheep. 


\section{Cervical mucus}

The supernatants obtained by washing the cervical mucus four times with $3 \mathrm{ml}$ saline contained $6 \mathrm{mg}$ protein. Eight precipitin arcs were detected after immunoelectrophoresis of the concentrated supernatant with anti-ovine serum, and gel electrophoresis at $\mathrm{pH} 8.9$ produced a protein pattern very similar to that of serum with the exception of fainter bands in the transferrin region and the absence of a band in the macroglobulin region. Ultracentrifugation of the gel phase in $6 \mathrm{M}$-guanidine hydrobromide followed by isolation of the macromolecules yielded $26 \mathrm{mg}$ glycoprotein and $22 \mathrm{mg}$ protein. The analysis of the glycoprotein showed that the content (as $\mathrm{g} / 100 \mathrm{~g}$ dry glycoprotein) was: galactose, 15.50; fucose, 8.80; glucosamine, 12.26; galactosamine, 9.64; $\mathrm{N}$-glycolylneuraminic acid, 6.55; nitrogen, 7.95; aspartic acid, 3.49 ; threonine, 9.60 ; serine, $4 \cdot 20$; proline, 1.73 ; glutamic acid, 6.27 ; glycine, $2 \cdot 15$; alanine, $3 \cdot 12$; valine, $4 \cdot 33$; isoleucine, $1 \cdot 12$; leucine, $4 \cdot 09$; tyrosine, $0 \cdot 99$; phenylalanine, 1.58; lysine, 1.31; histidine, 0.57 and arginine, 1.73. The sialic acid present was shown to be $N$-glycolylneuraminic acid by paper chromatography of the products of mild acid hydrolysis. Treatment of the glycoprotein with $0.1 \mathrm{M}$-sodium hydroxide containing $0.3 \mathrm{M}$-sodium borohydride at $45^{\circ} \mathrm{C}$ rapidly reduced its viscosity and resulted in destruction of $0.23 \mu \mathrm{mol}$ galactosamine, 0.23 $\mu \mathrm{mol}$ serine and $0.55 \mu \mathrm{mol}$ threonine per $\mathrm{mg}$ glycoprotein. Reduction of the native cervical mucus gel with $0 \cdot 1 \mathrm{M}$-dithiothreitol in $0 \cdot 1 \mathrm{M}$-tris- $\mathrm{HCl}$ buffer, $\mathrm{pH} 8$, also rapidly destroyed its gel properties.

\section{Discussion}

The secretion rates of oviducal fluid found for the ewes in this study were similar to those reported by other workers (Perkins, Goode, Wilder \& Henson, 1965; Iritani, Gomes \& VanDemark, 1969; Bellve \& McDonald, 1970). The concentration of protein in oviducal fluid was considerably lower than in serum and varied from day to day, but this variation was not related to the hormonal state of the animal, agreeing with the results of Perkins \& Goode (1966). The source of these variations may be changes in the amount of serum transudate entering the oviducal fluid but the cause of this is uncertain. It is possible that the presence of a cannula affects the amount of serum transudate.

In oviducal fluid from some species it has been shown that in addition to serum proteins small amounts of unique oviducal proteins can be detected electrophoretically (cow: Roberts, Parker \& Symonds, 1975; woman: Moghissi, 1970; monkey: Mastroianni, Urzua \& Stambaugh, 1970; rabbit: Urzua, Stambaugh, Flickinger \& Mastroianni, 1970; Feigelson \& Kay, 1972). In this investigation no unique oviducal proteins were found in ovine oviducal fluid sampled during the oestrous cycle. However, comparison of oviducal fluid and serum by gel filtration did reveal an increased amount of a component excluded from Sephadex G-200 in oviducal fiuid. A comparable fraction obtained from bovine oviducal fluid was similar analytically to the corresponding serum fraction (Roberts, Parker \& Symonds, 1975) but the excluded fraction from ovine oviducal fluid had a higher sugar content than the corresponding serum fraction. The analysis and size of the ovine excluded fraction suggest that it may contain some epithelial glycoprotein perhaps derived from the mucin detected histochemically in epithelial cells of the ovine oviduct (Hadek, 1953).

Uterine flushings were shown by Heap (1962) to give a good recovery of uterine luminal contents. Serum proteins accounted for most of the proteins in ovine uterine flushings but small amounts of 'uterine-specific' proteins were found. The number of these 'uterine-specific' proteins increased as gestation proceeded, and it is of interest that Rowson \& Moor (1967) have shown that at Day 13 of pregnancy a heat-labile component with antiluteolytic properties is formed by the embryonic membranes and is essential for a successful pregnancy in the ewe. Because the additional uterinespecific proteins were not detected until after Day 13 of pregnancy argues against any of these being the antiluteolytic factor but this possibility cannot be ruled out because of the small number of animals studied and the possibility of individual variation in the timing of appearance of the antiluteolytic factor. The normal oestrous cycle in the ewe does vary from 14 to 19 days and depends on the breed, stage of the breeding season and plane of nutrition (Terrill, 1968). 
The elevated activities of $\alpha$-L-fucosidase, $\beta$-D-galactosidase, $\alpha$-D-glucosidase, $\beta$ - $N$-acetylgalactosaminidase and $\beta-N$-acetylglucosaminidase in ovine uterine fluid parallel the activities of these glycosidases in bovine uterine fluid (Roberts \& Parker, 1974b), but the activities were higher in the sheep. As in the cow (Roberts, Parker \& Symonds, 1975), the activities of all the glycosidases in sheep were much less in oviducal fluid than in uterine fluid. The importance of carbohydrate-containing material such as glycoproteins and glycolipids on cell surfaces (Winzler, 1972; Hughes, 1973) gives rise to several potential functions for these glycosidases. Two possible mechanisms whereby glycosidases could control early embryonic development by altering membrane permeability and by initiating the adhesive phase of implantation have been discussed previously (Roberts \& Parker, 1974b).

The fluid obtained from the cervix possesses physical properties quite different from those of the oviducal and uterine fluids. The native cervical secretion has the typical rheological properties of epithelial mucus. Although serum proteins are found in the cervical secretion the component mainly responsible for the rheological properties of the secretion is an epithelial glycoprotein. Separation of this glycoprotein from serum proteins by the method of Gibbons \& Sellwood (1973) revealed that it had a chemical composition similar to that of other epithelial glycoproteins (Pigman $\&$ Hashimoto, 1963). It contained considerably more fucose and less $N$-glycolylneuraminic acid than bovine cervical glycoprotein (Gibbons, 1959) and in this respect it is intermediate between bovine and human cervical glycoprotein (Gibbons \& Roberts, 1963). In common with epithelial mucus from other sources the ovine mucus gel was rapidly liquefied by disulphide bond-breaking reagents and by alkali. Serine and threonine accounted for $30 \%$ of the amino acids and an alkali degradation study indicated that the sugar units are linked via $\mathrm{N}$-acetylgalactosamine to these hydroxyamino acids. Under the alkaline conditions used, more residues of hydroxyamino acids were destroyed than $N$-acetylgalactosamine, suggesting that some unsubstituted hydroxyamino acids were destroyed. McGuire \& Roseman (1967) have previously reported a similar observation with other epithelial glycoproteins and suggested that it was related to the large amount of hydroxyamino acids in these glycoproteins.

We thank the Population Council, Rockefeller University, New York, for financial support; Dr R. A. Gibbons for encouragement and advice during this investigation and for helpful criticism of the manuscript; Mr K. Collis for the amino acid analyses; and Mrs M. Marsh for her technical assistance during surgical cannulation of the sheep.

\section{References}

Awdeh, Z.L., Williamson, A.R. \& Askonas, B.A. (1968) Isoelectric focusing in polyacrylamide gel and its application to immunoglobulins. Nature, Lond. 219, 66-67.

BEDFORD, J.M. (1970) Sperm capacitation and fertilisation in mammals. Biol. Reprod. Suppl. 2, 128-158.

Bellve, A.R. \& McDonald, M.E. (1970) Directional flow of Fallopian tube secretion in the ewe at onset of the breeding season. J. Reprod. Fert. 22, 147-149.

Chang, M.C. (1972) In vitro fertilisation of mammalian eggs. J. Anim. Sci. 27, Suppl. 1, 15-22.

DAvis, B.J. (1964) Disc electrophoresis. II. Method and application to human serum proteins. Ann. N.Y. Acad. Sci. 121, 404-427.

DOWNs, F., HeRP, A., Moschera, J. \& Pigman, W. (1973) $\beta$-Elimination and reduction reactions and some applications of dimethylsulfoxide on submaxillary glycoproteins. Biochim. biophys. Acta 328, 182-192.

Feigelson, M. \& KAY, E. (1972) Protein patterns of rabbit oviducal fluid. Biol. Reprod. 6, 244-252.

Gibbons, R.A. (1959) Chemical properties of two mucoids from bovine cervical mucin. Biochem. $J$. 73, 209-217.

Gibbons, R.A. \& Mattner, P.E. (1971) The chemical and physical characteristics of the cervical secretion and its role in reproductive physiology. In Pathways to Conception, pp. 143-155. Ed. A. I. Sherman. Charles C. Thomas, Springfield.

Gibbons, R.A. \& Roberts, G.P. (1963) Some aspects of the structure of macromolecular constituents of epithelial mucus. Ann. N.Y. Acad. Sci. 106, 218-232.

GibBons, R.A. \& Sellwood, R. (1973) The macromolecular biochemistry of cervical secretions. In The Biology of the Cervix, pp. 251-265. Eds R. J. Blandau \& K. Moghissi. University of Chicago Press, Chicago.

Good, T.A. \& Bessman, S.P. (1964) Determination of glucosamine and galactosamine using borate buffers for modification of the Elson-Morgan and MorganElson reactions. Analyt. Biochem. 9, 253-262.

HADEK, R. (1953) Mucin secretions in the ewe's oviduct. Nature, Lond. 171, 750. 
Hamilton, P.B. (1963) Ion exchange chromatography of amino acids. A single column, high resolving, fully automatic procedure. Analyt. Chem. 35, 2055-2064.

HeAP, R.B. (1962) Some chemical constituents of uterine washings: a method of analysis with results from various species. J. Endocr. 24, 367-378.

Hughes, R.C. (1973) Glycoproteins as components of cellular membranes. Prog. Biophys. molec. Biol. 26, 189-268.

IRITANI, A., Gomes, W.R. \& VANDEMARK, N.L. (1969) Secretion rates and chemical composition of oviduct and uterine fluid in ewes. Biol. Reprod. 1, 72-76.

Mastroianni, L., Urzua, M.A. \& Stambaugh, R. (1970) Protein patterns in monkey oviducal fluid before and after ovulation. Fert. Steril. 21, 817-820

MATTNER, P.E. (1966) Formation and retention of the spermatozoan reservoir in the cervix of the ruminant Nature, Lond. 212, 1479-1480.

MCGuire, E.J. \& Roseman, S. (1967) Enzymatic synthesis of the protein-hexosamine linkage in sheep submaxillary mucin. J. biol. Chem. 242, 3745-3747.

Moghissi, K.S. (1970) Human Fallopian tube fluid. I. Protein composition. Fert. Steril. 21, 821-829.

Perkins, J.L. \& Goode, L. (1966) Effects of stage of the oestrous cycle and exogenous hormones upon the volume and composition of oviduct fluid in ewes. J. Anim. Sci. 25, 465-471.

Perkins, J.L., Goode, L., Wilder, W.A. \& Henson, D.B. (1965) Collection of secretions from the oviduct and uterus of the ewe. J. Anim. Sci. 24, 383-387.

Pigman, W. \& Hashimoto, Y. (1963) Recent studies of mucins and blood-group substances. Adv. Oral Biol. 1, 111-129.

Reisfeld, R.A., Lewis, U.J. \& Williams, D.E. (1962) Disc electrophoresis of basic proteins and peptides on polyacrylamide gels. Nature, Lond. 195, 281283.

Roberts, G.P. \& PARKer, J.M. (1974a) Macromolecular components of the luminal fluid from the bovine uterus. J. Reprod. Fert. 40, 291-303.

ROBERTS, G.P. \& PARKER, J.M. (1974b) An investigation of enzymes and hormone-binding proteins in the Iuminal fluid of the bovine uterus. J. Reprod. Fert. 40, 305-313.

Roberts, G.P., PARKer, J.M. \& SYMONDS, H.W. (1975) Proteins in the luminal fluid from the bovine oviduct. J. Reprod. Fert. 45, 301-313.

Rowson, L.E.A. \& Moor, R.M. (1966) Embryo transfer in sheep: the significance of synchronizing oestrus in the donor and recipient animal. $J$. Reprod. Fert. 11, 207-212.

Rowson, L.E.A. \& MooR, R.M. (1967) The inffuence of embryonic tissue homogenate infused into the uterus, on the life-span of the corpus luteum in the sheep. J. Reprod. Fert. 13, 511-516.

Rowson, L.E.A., LAwson, R.A.S., MooR, R.M. \& BAKER, A.A. (1972) Egg transfer in the cow: synchronization requirements. $J$. Reprod. Fert. 28, 427-431.

SCHEIDEGGER, J.J. (1955) Une micro-methode de l'immune électrophorèse. Int. Archs Allergy appl. Immun. 7, 103-110.

Terrill, C.E. (1968) Reproduction of sheep. In Reproduction in Farm Animals, pp. 265-277. Ed. E.S.E. Hafez. Lea \& Febiger, Philadelphia.

Urzua, M.A., Stambaugh, R., Flickinger, G. \& MastroianNi, L. (1970) Uterine and oviduct fluid patterns in the rabbit before and after ovulation. Fert. Steril. 21, 860-865.

WARREN, L. (1960) Thiobarbituric acid spray reagent for deoxy sugars and sialic acids. Nature, Lond. 186, 237.

WERNER, I. \& ODIN, L. (1952) On presence of sialic acid in certain glycoproteins and in gangliosides. Acta soc. med. upsal. 57, 230-241.

WINZLER, R.J. (1972) Glycoproteins of plasma membranes. Chemistry and function. In Glycoproteins. Their Composition and Function, Vol. 5, Part B, pp. 1268-1291. Ed. A. Gottschalk. Elsevier, Amsterdam.

Zaccharius, R.M., Zell, T.E., MorRison, J.H. \& WoODLOCK, J.J. (1969) Glycoprotein staining following electrophoresis on acrylamide gels. Analyt. Biochem. 20, 148-152. 